\title{
Deciphering the Provenance, Climate and Tectonic Settings of High Altitude Quaternary Deposits in Ladakh-NW Himalayas
}

\author{
Ravish Lal ${ }^{1 *}$, Mayuri Pandey ${ }^{2}$, N. C. Pant ${ }^{3}$ and H.S. Saini ${ }^{4}$ \\ ${ }^{1}$ Department of Geology, Ram Lal Anand College, University \\ of Delhi \\ ${ }^{2}$ Department of Geology, Institute of Science, Banaras Hindu \\ University \\ ${ }^{3}$ Department of Geology, University of Delhi
}

${ }^{4}$ Geological survey of India, Faridabad (Retd). *corresponding email address:
ravishgeology@gmail.com

Ladakh, a tectonically active highest plateau on earth, is uniquely located in low latitudes. The region preserves numerous and diverse sedimentary deposits representing extreme cold to warm climate conditions comprising thick moraines derived tills, incomplete sedimentary sequences of river terrace, alluvial fans and paleo-lacustrine deposits.

Quaternary deposits show that the depositional conditions fluctuated with low energy, arid to semi arid lacustrine deposits often sandwiched between the fluival to fluvioglacial deposits. The geochemistry of detrital sediments has been effectively used for the evaluation of tectonic setting and provenance studies (Bhatia, 1983, 1985a,b; Taylor and McLennan, 1985) In ancient collisional settings, the timing, duration, and spatial variation in tectonic activity is assessed mainly by analysis of the preserved sedimentary record in adjacent foreland basins (Garver et al., 1996). The chemical composition of sediments present in fluvial, glacio-fluvial and lacustrine deposits are diverse in nature and reflects significant variability in mineralogical composition. Gross chemical indicators such as CIA and CIW corroborate the lithological inferences. Tectonic discrimination diagrams involving both major as well as trace elements conform to the sourcing from active continental margins as well from the continental island arc.

The Optical Luminance dating technique was also used to generate chronology for these deposits which represents aggradational activities under fluctuating climatic condition from MIS 5e-MIS 3. 